\title{
Growth characteristics of bloom forming Mallomonas elongata (Synurophyceae) based on silicate and light intensity
}

\author{
Han Soon Kim ${ }^{1, *}$ and Kyung Lak Lee ${ }^{2}$ \\ ${ }^{1}$ Department of Biology, Kyungpook National University, Daegu 702-701, Korea \\ ${ }^{2}$ Department of Forensic Medicine, National Institute of Scientific Investigation, Seoul 158-707, Korea
}

A dominant planktonic bloom-forming species, Mallomonas elongata was isolated from a small shallow eutrophic pond. The growth characteristics of this species on variable silicate concentrations and light intensities were investigated in laboratory unialgal cultures. In culture condition of $15^{\circ} \mathrm{C}$, the maximum population growth and the highest growth rate of M. elongata occurred at a light intensity of $80 \mu \mathrm{mol} \mathrm{m}^{-2} \mathrm{~s}^{-1}$, and in culture condition of $18^{\circ} \mathrm{C}$, it exhibited the maximum population growth and the highest growth rates at a light intensity of $50 \mu \mathrm{mol} \mathrm{m}^{-2} \mathrm{~s}^{-1}$. Silicate concentration had no effect on the population growth and growth rate of M. elongata.

Key Words: bloom forming species; growth rate; light intensity; Mallomonas elongata; silicate; unialgal culture

\section{INTRODUCTION}

Silica-scaled chrysophytes (Synurophyceae) are important components of the species composition and biomass in freshwater environment worldwide, and the planktonic flagellate species Mallomonas elongata Reverdin is one of the most common and widespread synurophytes (Siver 1995, Kristiansen 2005). Some species of this algal group including $M$. elongata often form very dense blooms (Hoffmann and Wille 1992, Kim and Hwang 2001, Lee et al. 2005), which negatively affect the taste and odor of potable water (Nicholls 1995). Although the temperature, $\mathrm{pH}$, conductivity and nutrients (nitrogen and phosphorus) are primary factors controlling the distribution and seasonal occurrence of silica-scaled chrysophytes (Siver 1995), few comprehensive studies have been conducted on the growth characteristics of individual taxa. An important aspect to manage bloom formation in any group of organisms is an understanding of the relative importance of each environmental fac- tor in controlling the occurrence and distribution of the group in the field. Furthermore, understanding the ecophysiological growth characteristics of individual species through laboratory culture experiments is necessary to control and manage blooms. The autecological characteristics of specific species through culture experiments can show the influence of variable parameters such as temperature, $\mathrm{pH}$, nutrients (N, P, and $\mathrm{Si}$ ), and light on their growth and development. However, only a few studies on the growth characteristics of silica-scaled chrysophytes through in vitro laboratory culture experiments have been conducted (Healey 1983, Wee et al. 1991, Saxby-Rouen et al. 1997, Lee et al. 2007, Kim et al. 2008).

A dense bloom of $M$. elongata was observed during early spring in a small shallow eutrophic pond, located at the campus of Kyungpook National University, South Korea. Laboratory experiments using unialgal cultures of $M$. elongata isolated from the pond were performed (c) This is an Open Access article distributed under the terms of the Creative Commons Attribution Non-Commercial License (http://creativecommons.org/licenses/by-nc/3.0/) which permits unrestricted non-commercial use, distribution, and reproduction in any medium, provided the original work is properly cited.
Received 16 January 2011, Accepted 24 February 2011

*Corresponding Author

E-mail: kimhsu@knu.ac.kr

Tel: +82-53-950-5344 Fax: +82-53-953-3066 
to investigate the growth characteristics of this flagellate species at varying concentrations of Si and light intensities. A comparison of the natural and laboratory nutrient conditions required for optimal growth of this species is presented, and factors that may have caused discrepancies between the natural and laboratory conditions are discussed.

\section{MATERIALS AND METHODS}

Jido pond is located at Kyungpook National University, South Korea $\left(128^{\circ} 37^{\prime}\right.$ E, $\left.35^{\circ} 53^{\prime} \mathrm{N}\right)$. It has a surface area of approximately $200 \mathrm{~m}^{2}$ and a mean depth of $0.7 \mathrm{~m} . M$. elongata was isolated by pipetting single cells from Jido pond water samples collected with a plankton net (mesh size $40 \mu \mathrm{m}$ ) on May 5, 2005. Unialgal stock cultures were maintained in DY III medium buffered to $\mathrm{pH} 7.0$ with 2-( $N$-morpholino) ethanesulphonic acid (MES), at a temperature of $15 \pm 1^{\circ} \mathrm{C}$ and a light intensity of approximately $80 \mu \mathrm{mol} \mathrm{m}{ }^{-2} \mathrm{~s}^{-1}$ (cool white fluorescent light) on a $16: 8 \mathrm{~h}$ light : dark cycle.

For the Si experiments, clones selected from stock cultures in exponential growth were first adapted to $\mathrm{Si}$ limited media for 1 week, and then inoculated into fresh media at an initial cell density of approximately 800 cells $\mathrm{mL}^{-1}$. Growth experiments at various $\mathrm{Si}$ concentrations were conducted in triplicate in $125 \mathrm{~mL}$ Erlenmeyer flasks under continuous white fluorescent illumination of approximately $100 \mu \mathrm{mol} \mathrm{m}^{-2} \mathrm{~s}^{-1}$ intensity at $15^{\circ} \mathrm{C}$ and $\mathrm{pH} 6$, which was the optimal temperature and $\mathrm{pH}$ condition for growth in a previous study (Lee et al. 2005). The effect of light intensity on growth was examined at $\mathrm{pH} 6$ and two temperature conditions $\left(15^{\circ} \mathrm{C}\right.$ and $\left.18^{\circ} \mathrm{C}\right)$ to verify the results of our previous studies that showed a different effect based on strains among the same species (Lee et al. 2005, 2007). The light was measured with a TES 1332A digital lux meter (TES Electrical Electronic Corp., Taipei, Taiwan), and light values were converted to photon flux density $\left(\mu \mathrm{mol} \mathrm{m} \mathrm{m}^{-2} \mathrm{~s}^{-1}\right)$. The number of cells was enumerated at 2- or 3-day intervals, and counts were continued for 15 days until the stationary or decline phase was reached. Samples were fixed in Lugol's solution, and cell numbers were determined using a Sedgwick-Rafter chamber (PhycoTech Inc., St. Joseph, MI, USA).

Growth rates were expressed as $\mu=\left(\ln N_{2}-\ln N_{1}\right) /\left(t_{2}\right.$ $-t_{1}$ ), where $N_{2}$ and $N_{1}$ are the number of cells during the period of exponential growth at times $t_{2}$ and $t_{1}$, respectively. Specific growth rates $(\mu)$ were calculated during the exponential growth periods between day 0 and days 6 or 9 for each species. The $\mathrm{pH}$ of the medium was adjusted by adding of $\mathrm{HCl}$ or $\mathrm{NaOH}$. Strains are available from the culture collection of the authors.

\section{RESULTS}

\section{Growth characteristics under field conditions}

Details regarding environmental factors at the study site are described in a previous study (Lee et al. 2005). The pond water was highly eutrophic, and total nitrogen and phosphorus concentrations ranged from 3.714 to $8.702 \mathrm{mg} \mathrm{L}^{-1}$ and from 0.026 to $0.049 \mathrm{mg} \mathrm{L}^{-1}$, respectively (Lee et al. 2005).

The dominant species in the planktonic bloom were identified by electron microscopy as M. elongata and Synura petersenii. The seasonal patterns of total phytoplankton and the two synurophytes have been described by Lee et al. (2005) and Kim et al. (2008), respectively. The M. elongata population appeared in early spring, maintained a high density for a short period (March 21 to April 7), and accounted for $27.6-65.5 \%$ of the total phytoplankton population. At peak population abundance, the density of $M$. elongata was 17,600 cells $\mathrm{mL}^{-1}$, but gradually decreased as water temperature increased in April.

\section{Effect of Si on growth}

The population growth in unialgal cultures of M. elongata was examined at various Si concentrations (Fig. 1). Although M. elongata exhibited a maximum population growth at an Si concentration of $20 \mu \mathrm{mol}$, maximum

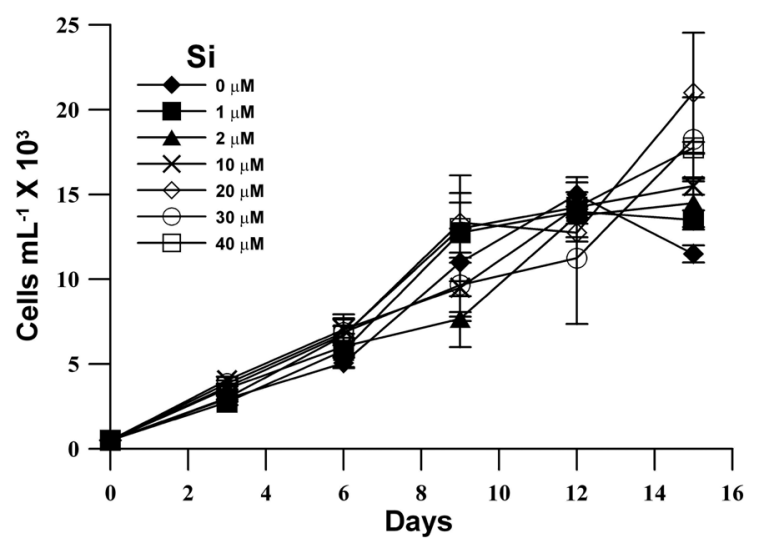

Fig. 1. Growth of Mallomonas elongata in various silicate concentrations. Bars indicate maximum and minimum values of three replicates. 


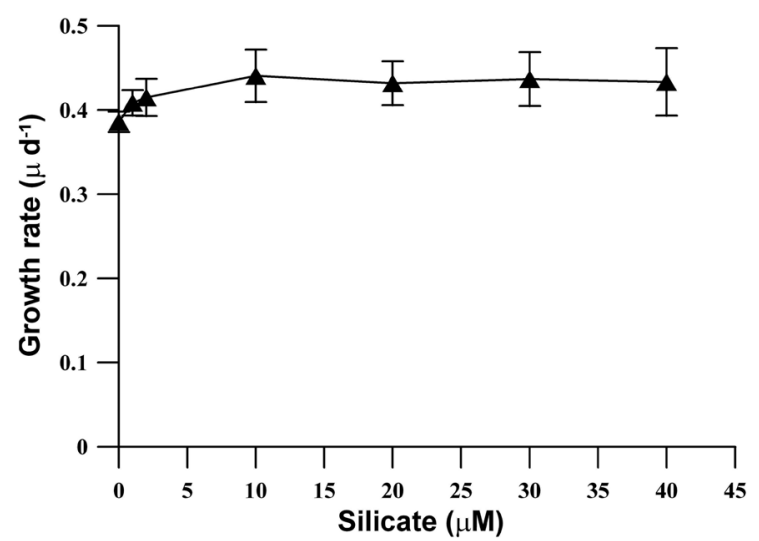

Fig. 2. Growth rates of Mallomonas elongata in various silicate concentrations.
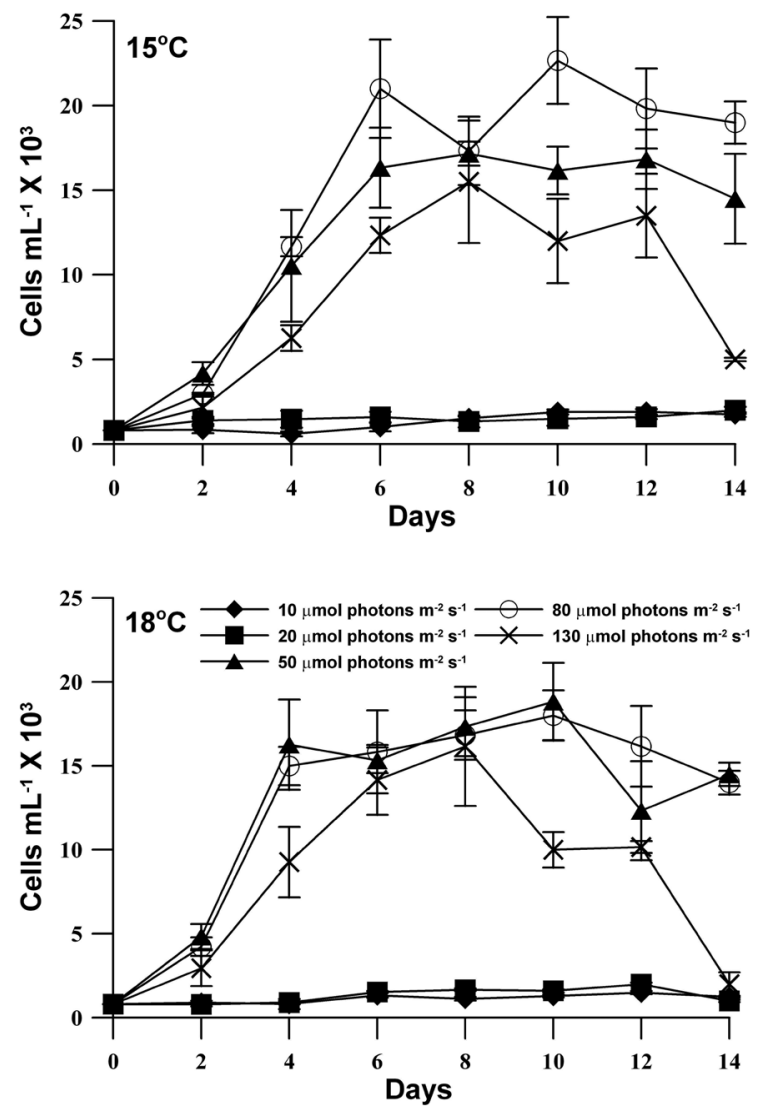

Fig. 3. Growth of Mallomonas elongata under various light intensities and under two temperature conditions.

population density was similarly reached at all $\mathrm{Si}$ concentrations, and a high population density $(15,000$ cell $\left.\mathrm{L}^{-1}\right)$ was also observed in Si-limited medium. Furthermore, the growth rates of $M$. elongata increased gradually as the Si concentration was increased to $10 \mu \mathrm{mol}$, but the higher concentration had no effect (Fig. 2).

\section{Effect of light intensity on growth}

The growth response of $M$. elongata exposed to variable light intensities at $15^{\circ} \mathrm{C}$ and $18^{\circ} \mathrm{C}$ is shown in Fig. 3 . In general, population growth patterns at both experiment temperature conditions similarly exhibited within the range of experimental light conditions (light intensities of 10-130 $\mu \mathrm{mol} \mathrm{m}^{-2} \mathrm{~s}^{-1}$ ). Under both experimental temperature conditions, M. elongata exhibited growth at all experimental light intensities, but very low growth appeared below a light intensity of $20 \mu \mathrm{mol} \mathrm{m} \mathrm{m}^{-2} \mathrm{~s}^{-1}$. Moreover, population growth increased as light intensity was increased up to an intensity of $80 \mu \mathrm{mol} \mathrm{m}^{-2} \mathrm{~s}^{-1}$. At a light intensity of $130 \mu \mathrm{mol} \mathrm{m}^{-2} \mathrm{~s}^{-1}$, population growth gradually increased, maximum density was reached at 8 days, and then rapidly declined. The maximum population density at $15^{\circ} \mathrm{C}$, occurred at a light intensity of $80 \mu \mathrm{mol} \mathrm{m}^{-2} \mathrm{~s}^{-1}$, whereas, the maximum population density was observed at a light intensity of $50 \mu \mathrm{mol} \mathrm{m} \mathrm{m}^{-2} \mathrm{~s}^{-1}$ at $18^{\circ} \mathrm{C}$. The growth rates of $M$. elongata gradually increased with increasing light intensity up to $50-80 \mu \mathrm{mol} \mathrm{m}^{-2} \mathrm{~s}^{-1}$. The growth rate at the lower temperature $\left(15^{\circ} \mathrm{C}\right)$ was higher than at the higher temperature $\left(18^{\circ} \mathrm{C}\right)$ under light intensities less than 20 $\mu \mathrm{mol} \mathrm{m} \mathrm{m}^{-2} \mathrm{~s}^{-1}$. In contrast, the growth rate at a higher temperature $\left(18^{\circ} \mathrm{C}\right)$ higher than at a lower temperature $\left(15^{\circ} \mathrm{C}\right)$ under higher light intensities greater than $50 \mu \mathrm{mol} \mathrm{m}^{-2} \mathrm{~s}^{-1}$. The maximum growth rates of M. elongata at $15^{\circ} \mathrm{C}$ and $18^{\circ} \mathrm{C}$ occurred at $80 \mu \mathrm{mol} \mathrm{m}^{-2} \mathrm{~s}^{-1}$ and $50 \mu \mathrm{mol} \mathrm{m}^{-2} \mathrm{~s}^{-1}$, respectively (Fig. 4).

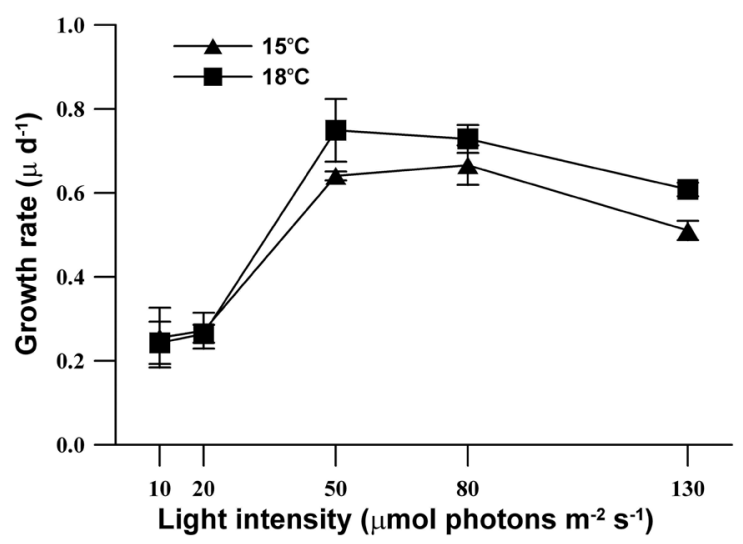

Fig. 4. Growth rates of Mallomonas elongata under various light intensities. 


\section{DISCUSSION}

Dense blooms of $M$. elongata were observed in early spring from a small eutrophic pond. M. elongata is one of the most common and widely distributed species of silica-scaled chrysophytes (Siver 1995, Kristiansen 2005). An investigation into the growth characteristics of individual species in the field as well as ecophysiological studies of selected species through laboratory culture experiments are needed to manage any algal bloom.

Water temperature, $\mathrm{pH}$, conductivity and inorganic nutrients $\left(\mathrm{PO}_{4}\right.$ and $\left.\mathrm{NO}_{3}\right)$ are major limiting factors affecting the distribution and growth of silica-scaled chrysophytes (Siver 1995, Kristiansen 2005). Si and light intensity are also important factors for development in this algal group (Sandgren et al. 1996, Saxby-Rouen et al. 1997, Kim et al. 2009).

On a global basis, $M$. elongata has been classified as a cold water organism (with an average weighted mean temperature $<12^{\circ} \mathrm{C}$ ), a high $\mathrm{pH}$ group (with weighted mean values above $\mathrm{pH}$ 7), and an organism that prefers eutrophic water (Siver 1995). However, a study on the growth of $M$. elongata regarding $\mathrm{Si}$ concentrations and light intensities has not been available until now. Additionally, culture studies concerning species-specific variations have rarely been performed, particularly with respect to the effects of nutrients (Si) and light intensity on growth of the genus Mallomonas.

Saxby (1990) observed that adding reactive Si to silicon deprived batch cultures increased growth rates in all experiments. In the present study, although the growth rate of $M$. elongata increased as the Si concentration increased up to $10 \mu \mathrm{mol}$, growth rates were similar at all tested Si concentrations ranges. Overall, high population growth was exhibited at all ranges of Si concentrations between 0 and $40 \mu \mathrm{mol}$. This result was similar to a report that the population growth and growth rates of three strains of $M$. caudata are not affected by Si concentration (Kim et al. 2009). The present study results support previous work that scale-bearing chrysophytes (S. petersenii) do not require large quantities of Si for growth, and that dramatic population growth can be achieved under severe Si-limited conditions (Sandgren and Barlow 1989, Kim et al. 2009).

In this study, $M$. elongata showed an inhibition of growth with light intensities greater than $80 \mu \mathrm{mol} \mathrm{m}{ }^{-2} \mathrm{~s}^{-1}$, and saturating light intensity at a lower temperature was higher than at a higher temperature. In contrast to that seen in Synura sphagnicola (Healey 1983), the growth rates of $M$. elongata increased at the same light intensity as that which increased culture temperature. Moreover, the growth characteristics of M. elongata under two experimental temperature conditions showed similar results to our previous study (Lee et al. 2007). These results were similar to reports of ours and other studies showing that growth inhibition appeared in certain strains of $S$. petersenii and M. caudata under high light intensity (Meeson and Sweeney 1982, Kim et al. 2008, 2009). The characteristics of $M$. elongata shown in this study support our previous reports that planktonic silica-scaled chrysophytes have strain-specific growth characteristic based on individual environment factors such as temperature and $\mathrm{pH}$, nutrients and light intensity (Kim et al. 2008, 2009).

Previous studies (Lee et al. 2005, 2007) have shown that two strains of M. elongata isolated from different water bodies have significantly different growth characteristics under the same temperature condition $\left(18^{\circ} \mathrm{C}\right)$. The optimum growth of the strain that we used in this study appeared at $15^{\circ} \mathrm{C}$, whereas very low population growth was observed at $18^{\circ} \mathrm{C}$. The other strain isolated from a different reservoir showed high population growth and growth rates at both $15^{\circ} \mathrm{C}$ and $18^{\circ} \mathrm{C}$. In the present study, the same strain isolated from Jido pond located in Kyungpook National University, which showed very low growth rates in a previous study, displayed a higher growth rate at $18^{\circ} \mathrm{C}$ than that at $15^{\circ} \mathrm{C}$ at light intensities greater than at $50 \mu \mathrm{mol} \mathrm{m} \mathrm{m}^{-2} \mathrm{~s}^{-1}$. This could have resulted from differences in $\mathrm{pH}$.

In conclusion, these results supports previous reports in that each strain among the same silica-scaled chrysophytes species isolated from different water bodies has strain-specific growth adaptations for various environmental factors. These results suggest that population development and succession of silica-scaled chrysophytes including $M$. elongata could be governed by individual factors as well as an interaction between various factors such as temperature, $\mathrm{pH}$, nutrients, and light intensity. Further culture studies on the influence of the interaction between these environmental factors on growth and development of individual species of this algal group will be required to fully understand how to controll and manage algal blooms.

\section{ACKNOWLEDGEMENTS}

This work was supported by a grant from the Advanced Biomass R\&D Center (ABC) of Korea (ABC-20100029723), funded by the Ministry of Education, Science 
and Technology.

\section{REFERENCES}

Healey, F. P. 1983. Effect of temperature and light intensity on the growth rate of Synura sphagnicola. J. Plankton Res. 5:767-774.

Hoffmann, L. \&Wille, E. 1992. Occurrence of a metalimnetic summer peak of Mallomonas caudata (Synurophyceae). Nord. J. Bot. 12:465-469.

Kim, H. S. \& Hwang, K. J. 2001. Occurrence and seasonal changes of silica-scaled chrysophytes in Kachang Dam Reservoir. Algae 16:421-427.

Kim, J. H., Lee, K. L. \& Kim, H. S. 2009. Effect of nutrients and light intensity on growth of Mallomonas caudata (Synurophyceae). Nord. J. Bot. 27:516-522.

Kim, J. H., Shin, M. O., Lee, K. L. \& Kim, H. S. 2008. Effect of environmental conditions on the growth of Synura petersenii (Synurophyceae) in vitro and two eutrophic water bodies in Korea. Nova Hedwigia 86:529-544.

Kristiansen, J. 2005. Golden algae: a biology of chrysophytes. A. R. G. Gantner Verlag K. G., Ruggell, 167 pp.

Lee, K. L., Kim, J. H., Yoon, H. -S. \& Kim, H. S. 2005. Effects of temperature and $\mathrm{pH}$ on seasonal changes and growth characteristics of a bloom forming Mallomonas elongata (Synurophyceae). Korean J. Limnol. 38:503-509.

Lee, K. L., Yoon, H. -S., Kim, Y. J. \& Kim, H. S. 2007. Growth characteristics of three Mallomonas species (silicascaled chrysophytes) at different temperatures and $\mathrm{pH}$. Nord. J. Bot. 25:113-118.

Meeson, B. W. \& Sweeney, B. M. 1982. Adaptation of Ceratium furca and Gonyaulax polyedra (Dinophyceae) to different temperatures and irradiances: growth rates and cell volumes. J. Phycol. 18:241-245.

Nicholls, K. H. 1995. Chrysophyte blooms in the plankton and neuston of marine and freshwater systems. In Sandgren, C. D., Smol, J. P. \& Kristiansen, J. (Eds.) Chrysophyte Algae: Ecology, Phylogeny and Development. Cambridge University Press, Cambridge, pp. 181-213.

Sandgren, C. D. \& Barlow, S. B. 1989. Siliceous scale production in chrysophyte algae. II. SEM observations regarding the effects of metabolic inhibitors on scale regeneration in a laboratory population of scale-free Synura petersenii cells. Nova Hedwigia 95:27-44.

Sandgren, C. D., Hall, S. A. \& Barlow, S. B. 1996. Siliceous scale production in chrysophyte and synurophyte algae. I. Effects of silica-limited growth on cell silica content, scale morphology, and the construction of the scale layer of Synura petersenii. J. Phycol. 32:675-692.

Saxby, K. J. 1990. The physiological ecology of freshwater chrysophytes with special reference to Synura petersenii. Ph. D. dissertation, Birmingham University, Birmingham, UK, $170 \mathrm{pp}$.

Saxby-Rouen, K. J., Leadbeater, B. S. C. \& Reynolds, C. S. 1997. The growth response of Synura petersenii (Synurophyceae) to photon flux density, temperature, and $\mathrm{pH}$. Phycologia 36:233-243.

Siver, P. A. 1995. The distribution of chrysophytes along environmental gradients: their use as biological indicators. In Sandgren, C. D., Smol, J. P. \& Kristiansen, J. (Eds.) Chrysophyte Algae: Ecology, Phylogeny and Development. Cambridge University Press, Cambridge, pp. 232268.

Wee, J. L., Millie, D. F. \& Walton, S. P. 1991. A statistical characterization of growth among clones of Synura petersenii (Synurophyceae). J. Phycol. 27:570-575. 